\title{
The Performance of Agricultural Extension Workers on Empowerment and Independent Smallholder Farmer in Riau Province, Indonesia
}

\author{
Rosnita \\ Department of Agribusiness, Faculty of Agriculture, Riau University \\ Pekanbaru, Riau, Indonesia. E-mail: rosnita_ita@yahoo.co.id \\ Roza Yulida \\ Department of Agribusiness, Faculty of Agriculture, Riau University \\ Pekanbaru, Riau, Indonesia. E-mail: rozayulida@lecturer.unri.ac.id \\ Novia Dewi \\ Department of Agribusiness, Faculty of Agriculture, Riau University \\ Pekanbaru, Riau, Indonesia. E-mail: dewinovia642@gmail.com \\ Arifudin \\ Department of Agribusiness, Faculty of Agriculture, Riau University \\ Pekanbaru, Riau, Indonesia. E-mail: arif_udin@yahoo.com \\ Yulia Andriani \\ Department of Agribusiness, Faculty of Agriculture, Riau University \\ Pekanbaru, Riau, Indonesia. E-mail: yulia.andriani@lecturer.unri.ac.id
}

(Received: Jan 31, 2017; Reviewed: Mar 1, 2017; Accepted: Jun 1, 2017)

\section{DOI: http://dx.doi.org/10.20956/ijas.v5i1.1173}

\begin{abstract}
The difference between the production and productivity of smallholders with private estates describe that the extension is still not carry out the role of extension in accordance with Act No 16 of 2006 or that known as SP3K. This will certainly have an impact on performance and memandirikan educator in empowering farmers. Performance can be seen how the extension educator preparation, implementation and evaluation and reporting on the role of counseling was run. The limited number of extension workers to meet one on one village extension will result in the workload becomes larger extension. This study aims to analyze: (1) The performance of agricultural extension; (2) The level of farmer empowerment, and (3) Independence of farmers in the cultivation of rubber and oil palm. Research methods using ex post facto, (analyze and assess the factual events that occurred on the field), with a sample of 240 farmers (120 smallholders and 120 rubber farmers from four districts in Riau province. Analysis using the Scale Likert's Summated Rating (SLR). The results of the study illustrate that the extension has been conducting outreach with good especially in preparatory education. Activities undertaken have made quite helpless farmers, but farmers still unable to act independently plantations in doing farming oil palm and rubber. Based on our research, it is suggested extension workers to improve their performance in the extension program, for farmers to improve the quality of human resources and productive economic business for rubber and oil palm commodities, and the government should make efforts to improve the farmers' marketing institutions to reduce the dependence of farmers on toke.
\end{abstract}

Keywords: Performance; Empowerment; Independent 


\section{Introduction}

Agricultural revitalization implemented through agricultural development that emphasizes the growth of agribusiness ventures, both in the upstream, on-farm, and downstream as well as business support services (Decree of SKKNI Agriculture, 2010). The quality of human resources is still low and causes of low agricultural productivity generated. This fact also seen in the production and productivity of plantations, especially oil palm and rubber produced in the Riau Province.

Act No. 16 of 2006 concerning Agricultural Extension System, Fisheries and Forestry confirm that the state Minister for Agriculture extension has a strategic role to promote agriculture in Indonesia. Extension agent plays an important role in improving the knowledge of farmers through extension activities.

Human resources development (HRD) is important in agriculture extension to transfer technology and knowledge from agricultural research centres to farmers. Improving human resource development (HRD) within rural community is essential for agriculture and community development. Extension workers are professionals in the extension system responsible for developing individuals in the community (Khalil et al, 2008). The success of extension workers to empowering and establishing the farmers is determined by various factors, especially the factors that will influence the extension workers (such as characteristics, independence, and social system) of the extension workers, motivation of extension, the competence of extension, and the role which has been run extension in their duties. All these factors will describe the performance extension that will be imaged on the planning, implementation, and evaluation related to the extension workers duties. In fact an extension workers is responsible for two until four guided villages, polivalent extension and limitation of training for them.

The research result Rosnita et al. (2016) on the Impact of Independence Extension towards empowerment Palm Farmers pattern Governmental in Riau province illustrates that the extension is still limited in the opportunity in training so that intellectual independence extension is still lacking, especially in preparing extension materials, making the implementation of the education becomes more attractive, And in determining the timing of the implementation of extension activities. These conditions result in an extension in fostering farmers are not performing well that will be visible on the readiness of the extension in preparing extension activities, in the implementation of counseling and evaluation and reporting that will affect to the performance and independent educator in empowering farmers. Added by Adefila (2012), on the basis of the findings, one recommends that the government concerned should address the constraints that affect agricultural extension workers' performance once and for all and it will go a long way to boost job performance. Moreover, improvement in attitude of workers can as well result in a remarkable increment in agricultural productivity.

Data of Director General of Plantations (2014), in 2013 the province of Riau is a province that has the largest oil palm 
plantations with a total area covering an area of 2.30 million hectares, followed by successive North Sumatra Province covering an area of 1.39 million hectares, Kalimantan Tengah Province, covering an area of 1,16 million hectares and South Sumatera with an area of 1.11 million hectares and the other provinces. Areas in the province potential in the development of commodities namely Rokan Hilir and Pelalawan in developing oil palm, Kampar and Kuantan Singingi in development of commodity rubber.

Rokan Hilir placed second for plantation area compared to other districts in the province of Riau, which reached 257.373 hectares (Statistics Plantation Riau Province, 2013). Kubu district is one of the districts that have the potential in the production of palm oil, based on the data (Plantation Office Rokan Hilir 2013) extensive palm plantations Kubu district reached 7203.13 ha with productivity $2314.82 \mathrm{Kg} / \mathrm{Ha}$. Besides Rokan Hilir, Pelalawan has potential in the development of oil palm to palm land area of 305.630 hectares and production in 2013 reached 1.147.126 tons of fresh fruit bunches (FFB) where the District is a district Langgam has the potential to have as much land area of 12.506 ha of oil palm with production reaching 856.751 tonnes (BPS Riau, 2014).

The development of rubber plantations in Indonesia is widespread throughout the region. The largest rubber plantation in the province of South Sumatra amounting to 675.437 hectares. Meanwhile, Riau province is at number four. In the development of rubber, rubber plantation area in Riau Province is currently about 500.949 hectares, which is owned by independent smallhold- ers around 480.929 hectares with a production of 313.318 tons/year (Plantation Office of Riau Province, 2013). According to data from Statistics Agency in 2013 in Kampar regency rubber production reached 78.031 tons/year with total area of $101.597 \mathrm{ha}$. Kampar Kiri is a rubber-dominant districts in Kampar regency with rubber production in 2013 reached 3.278 tons/year with total area of 9.467 hectares (Kampar Plantation Office, 2013). In addition to Kampar Regency Kuantan Singingi is one of the districts with extensive rubber plantations in 2013 was $150.565 \mathrm{Ha}$.

Reliable human resource will be able to improve the performance of the public service. Education Coordinating Board (Bakorluh) Riau Province has a standard for assessing the performance of agricultural extension. Extension Coordinating Board set three aspects are assessed to determine the performance extension, namely 1) the preparation of agricultural extension, 2) the implementation of agricultural extension and 3) Evaluation and Reporting.

This study aims to assess: a) What was the performance extension in preparing extension activities, b) Is the extension has been carrying out activities properly instructed, and c) Is the extension is already evaluating and reporting extension activities that have been implemented.

\section{Method}

This research is a survey research. Survey research conducted by the method of analysis design ex post facto, to analyze and assess the factual events that occurred on the field (Nazir, 2003). The choice of 
location was purposively. Of the 12 districts / cities have been selected 4 District, which is Pelalawan and Rokan Hilir for counseling on oil palm growers, Kuantan Singingi and Kampar for counseling on rubber farmers, consideration of the location based on the number of farmers the most. Besides key informants were taken as samples in order to obtain more in-depth information.

The primary data obtained through interviews to using questionnaires in an- swering the research objectives. The variables and indicators as shown in Table 2. To measure the The performance of extension, empowerment and Independence of farmers using Likert Scale's analysis. Likert scale is a scale used to measure attitudes, opinions, and perceptions of a person or a group of social phenomenon (Sugiyono, 2011). The range of scores on the performance extension, empowerment and Independence of farmers amounted to 0.79 (Table 3).

Table 1. The amount and source of key informants

\begin{tabular}{cllc}
\hline No & \multicolumn{1}{c}{ Key informan } & \multicolumn{1}{c}{ Doer } & Amount (person) \\
\hline 1 & Institutional Provincial Extension & Bakorluh Province & 1 \\
2 & Plantation Office of Riau Province & Riau Plantation Office & 1 \\
3 & District Education Executive Agency & Counseling Agency Kabupaten & 1 each regency \\
4 & Counseling Center for the District & Kepala BPP & 1 each district \\
\hline
\end{tabular}

Table 2. The variables and indicators of performance

\begin{tabular}{llll}
\hline \multicolumn{1}{c}{ Variable } & & \multicolumn{1}{c}{ Indicators } & \multicolumn{1}{c}{ Source } \\
\hline The performance of & 1. & Preparation of agricultural extension \\
Agricultural & 2. & Implementation of agricultural extension \\
Extension & 3. & Evaluation and reporting & $\begin{array}{l}\text { Agency Counseling } \\
\text { and Human Resource } \\
\text { Development of } \\
\text { Agriculture (2012) }\end{array}$ \\
\hline Farmer & & & TKP3 KPK (2004) \\
empowerment & 1. & Human Resources Human Resources & \\
& 2. & Productive Economy & \\
Farmers & 3. & Institutional & \\
independence & 1. & Independence of decision-making in choosing the type & Lestari, 2011 \\
& 2. & Independence of decision-making in the fulfillment of & \\
& & production facilities & \\
& 3. & Independence of decision-making in pricing & \\
& 4. & Independence of decision-making to take in marketing & \\
\hline
\end{tabular}

Table 3. Category and a score on the performance extension, empowerment and independence of farmers

\begin{tabular}{|c|c|c|c|c|}
\hline \multicolumn{3}{|c|}{ Category } & \multicolumn{2}{|c|}{ Value } \\
\hline $\begin{array}{l}\text { Performance } \\
\text { Extension }\end{array}$ & $\begin{array}{l}\text { Empowerment of } \\
\text { Farmers }\end{array}$ & $\begin{array}{l}\text { Independence of } \\
\text { farmers }\end{array}$ & Scale & Score \\
\hline Very Poor (STB) & $\begin{array}{l}\text { Very Less-Empowerment } \\
\text { (STB) }\end{array}$ & $\begin{array}{l}\text { Very Less-Independence } \\
\text { (STM) }\end{array}$ & 1 & $1,00-1,79$ \\
\hline Poor (TB) & Less Empowerment (TB) & $\begin{array}{l}\text { Less-Indenpendence } \\
\text { (TM) }\end{array}$ & 2 & $1,80-2,59$ \\
\hline Good Enough (CB) & $\begin{array}{l}\text { Empowerment Enough } \\
\text { (CB) }\end{array}$ & $\begin{array}{l}\text { Idependence Enough } \\
\text { (CM) }\end{array}$ & 3 & $2,60-3,39$ \\
\hline Good (B) & Empowerment (T) & Independence (M) & 4 & $3,40-4,19$ \\
\hline Very Good (SB) & Very Empowerment (ST) & $\begin{array}{l}\text { Very Indenpendence } \\
\text { (SM) }\end{array}$ & 5 & $4,20-5,00$ \\
\hline
\end{tabular}




\section{Results and Discussion}

David and Samuel (2014) said that the role of extension in the 21 century should be that of the sustainers, catalysts, agency of empowerment, human infrastructure, contextualizes synergists', and collaborators. Extension services should also re-appraise its work periodically and modify its programs to suit the changing conditions. The performance of "is the real behavior displayed by everyone as the resulting performance by a person in accordance with its role". Simanjuntak Payaman J (2005), that the performance is the level of achievement of results on the implementation of certain tasks. Rahman and Muh Azis (Sedarmayanti, 2001) defines the achievement of performance that a person, group of persons or institutions related to the position and the role they played. Casio revealed, performance measurement is the process of evaluating the performance of employees in order to develop the potential of the employee. Performance measurement is the process of evaluating or assessing employee performance. One way to measure performance is by way of rating scale (Sapar, 2011).

\subsection{The Performance of Agricultural Ex- tension}

Sapar (2012), mentions the performance extension is determined at the level of achievement of the goals set by the organization of agricultural extension.

\subsubsection{The performance of extension in prep- aration}

Extension activities are not activities that are sudden or incidental, but must be planned or prepared as best as possible.
The activities prepared must be based on the needs of farmers. Good preparation may only be achieved if the extension to know in advance about the state of physical, economic, social and local farmers. Information is the basis in making preparations extension. This is in accordance with Rehman et al (2013). They said that, in agriculture, the role of information cannot be over emphasized in enhancing the agricultural development. Information is crucial for increasing agricultural production and improving marketing an distribution strategies. Their result of study therefore reveal that there is a dire need for the effective implementation of policies on adequate and easy accessibility of agricultutal information to the farmers to enhance the agricultural production.

Before carrying out an educator extension activities should prepare to guide the drafting of the Definitive Group (RDKK), preparation of agricultural extension programming and make the Annual Work Plan for Agriculture (RKTPP). The performance of educator in preparing extension activities can be seen in Table 4 .

Table 4 illustrates that agricultural extension is already preparing with excellent outreach activities that will be implemented is shown with an average score of 4.58. Very good preparation counseling conducted by the extension due to: 1) In accordance with the duties and functions as the extension, has an obligation to prepare and report maps and the potential of the working area in each year, which in some areas is associated or connected with the professional allowance as educator will paid, 2) the success or performance extension will be drawn from the 
Table 4. The performance of educator in preparing agricultural extension in Riau Province

\begin{tabular}{clcc}
\hline No & \multicolumn{1}{c}{ Preparation of Agricultural Extension } & Rate & Criteria \\
\hline 1 & Make a data potential areas & 4.88 & Very Good \\
2 & Assisting farmers in preparing RDKK & 4.17 & Good \\
3 & Involved in the preparation of village and district program & 4.54 & Very Good \\
4 & Make the annual work plan of agricultural extension (RKTPP) & 4.75 & Very Good \\
\hline & Average & 4.58 & Very Good \\
\hline
\end{tabular}

success of farmers, so the extension should guide and nurture the farmers in preparing the Definitive Plan Group (RDK) and RDKK, 3) in order educator program in line with the village and sub-district, the involvement of extension in programming villages and districts is very high, in order to program the village and district produced will be able to support the extension itself, 4) a large part of the extension to make the Annual Work plan for Agriculture (RKTPP) consisting of state territory, goal setting, setting of the problem, and plans activities, since this is an obligation for every extension.

\subsubsection{The performance of extension in the} Implementation extension workers

Based on the Ministry of Agriculture Regulation No. 91/Permentan/ OT.140/9/2013, performance educator in the implementation of agricultural extension can be seen from: 1) carry out dissemination or distribution of extension materials according to the needs of farmers, 2) carry out the implementation of agricultural extension methods in the target area, 3) capacity building of farmers to access market information, technology, infrastructure, and financing, 4) to cultivate and develop the institutional farmers from the aspect of quantity and quality, 5) grow and develop economic institutions farmer from quantity and quality aspects, 6) increasing productivity agricultural farmers. The performance of educator in the implementation of the extension can be seen in Table 5.

Table 5 shows the performance of educator in the implementation of agricultural extension in Riau Province has been "Pretty Good" as indicated by the average score of 2.90. This valuation assessed on 10 indicators that have been set by the Education Coordinating Board (BAKORLU) Riau Province. In the implementation of education that still needs to be improved, especially in terms of the implementation of the extension in the form of demonstrations and courses are still with frame rates are still very minimal done by an educator, according to an educator of limited funds Operational in carrying out duties as educator is one of the obstacles in order to perform demosntrasi and courses. On the other hand the ability to develop economic institutions farmers must be increased again by educator.

\subsubsection{The performance extension in evalua- tion and reporting \\ Evaluation is a process to determine} the relevance, efficiency, effectiveness, and impact of extension activities that have been carried out in accordance with the objectives to be achieved systematically and objectively. The purpose of the evaluation are: 1) to 
Tabel 5. The performance of educator based on the implementation of agricultural extension in Riau Province

\begin{tabular}{|c|c|c|c|}
\hline No & Implementation of Agricultural Extension & Rate & Criteria \\
\hline 1 & $\begin{array}{l}\text { Implement dissemination of material according to the needs of } \\
\text { farmers (within } 1 \text { year) }\end{array}$ & 2.92 & Good Enough \\
\hline 2 & The frequency of visits or face to face in one year target region & 4.04 & Good \\
\hline 3 & Applying the method of demonstration in the last 1 year & 2.57 & Not Good \\
\hline 4 & Implement / apply meetings in the last 1 year & 2.79 & Good Enough \\
\hline 5 & $\begin{array}{l}\text { Frequency of applying the method of the course in the last } 1 \\
\text { year }\end{array}$ & 1.46 & Very Good \\
\hline 6 & $\begin{array}{l}\text { To increase the capacity of farmers to access farming } \\
\text { information }\end{array}$ & 3.33 & Good Enough \\
\hline 7 & $\begin{array}{l}\text { Growing a farmer groups / group union of quality and quantity } \\
\text { aspects }\end{array}$ & 3.83 & Good \\
\hline 8 & Improving farmers' groups from quantity and quality aspects & 2.75 & Good Enough \\
\hline 9 & $\begin{array}{l}\text { Facilitating economic growth and development institution } \\
\text { farmers }\end{array}$ & 1.67 & Very Not Good \\
\hline \multirow[t]{2}{*}{10} & $\begin{array}{l}\text { educator capability to increase production commodity in } \\
\text { WKPP }\end{array}$ & 3.54 & Good \\
\hline & Average & 2.90 & Good Enough \\
\hline
\end{tabular}

collect important data for planning the next program, find out the target, 2) know the goals/objectives of the program/activities have been achieved, 3) be aware of changes that have occurred as a result of the intervention program, 4) identify strengths and humadity in the planning and implementation of programs, and 5) determine the progress of implementation of extension has been achieved.

The benefits of the evaluation in order to determine the level of farmers behavior changes after counseling carried out, and 2) improvement of the implementation of the next extension.

Reporting must be done by an educator of the activities that have been carried out and the results obtained from the evaluation carried out during the run (monthly report) or the activity has ended (annual report). The purpose of the reporting is done in order to know the progress of the implementation of the extension, identified the problems encountered in the field and troubleshooting actions, can do early prevention and obtaining feedback for corrective action next. The performance of evaluation and reporting are presented in Table 6 .

Table 6. The performance of evaluation and reporting in Riau Province

\begin{tabular}{cccc}
\hline No & Evaluation and Reporting & Rate & Criteria \\
\hline 1 & $\begin{array}{l}\text { Frequency evaluate the implementation } \\
\text { of agricultural extension }\end{array}$ & 3.29 & Good Enough \\
2 & $\begin{array}{l}\text { Frequency evaluate the implementation } \\
\text { of agricultural extension }\end{array}$ & 3.92 & Good \\
\hline Average & 3.60 & Good \\
\hline
\end{tabular}

Table 6 explains that the educator has been relatively good performance in conducting the evaluation and reporting indicated with a score of 3.60. Evaluating the frequency is still in the category quite well due to the limited frequency performed by educator (only twice), the evaluation should be done every time educator conduct extension activities in order to take corrective action as early as possible. Implementation of reporting is already better than the evaluation, because the educator did four times a year reporting in which is monthly 
reports, quarterly and semi annual reports and annual reports.

\subsubsection{Recapitulation of the performance of} agricultural extension

Farmers are at the forefront as the leading actors of changes in agricultural development activities, while the educator as an agent to change the behavior of farmers. With the expected extension activities undertaken farmers in conducting agricultural activities with better farming, better business, and better living in accordance with the purpose of extension itself. Of course, success will be achieved by the farmers inseparable from the performance of educator in conducting counseling. The performance of educator in conducting extension activities are presented in Table 7.

Table 7. Recapitulation of the performance of Agricultural Extension in Riau Province

\begin{tabular}{clcl}
\hline No. & \multicolumn{1}{c}{ Performance } & Rate & \multicolumn{1}{c}{ Criteria } \\
\hline 1 & Preparation of Agricultural Extension & 4.58 & Very Good \\
2 & Performance of Agricultural Extension & 2.90 & Good Enough \\
3 & Evaluation and Reporting & 3.60 & Good \\
\hline & Average & 3.41 & Good \\
\hline
\end{tabular}

Table 7 explains that the performance educator in extension activities of plantation commodities has been well illustrated by a score of 3.41. That is because the educator is already preparing activities denggan excellent extension before implementing extension activities. Extension Agent prepares the data potential of the region, is involved in planning a program villages and districts as well as making annual work plans. This is an obligation that must be carried out educator associated with the position held and the conditions to be met as a basis for assessing performance in accordance with the functional educator as the educator bears. Besides, an educator is also required to conduct evaluations and reporting.

\subsection{Empowerment of Smallholders Gov- ernmental Pattern}

Empowerment is giving an opportunity to freely choose various alternatives and make decisions in accordance with the level of consciousness. Ability and desire them and give them the opportunity to learn from the successes and failures in responding to the changes so that they can control their future (Bryant dan White 1982 inside Mardikanto 2009). Bahua etal (2016) said that, the form of community empowerment of farmers through institutional strengthening barns village, for example through capacity building human resources, strenghtening capital farming and development system resinous warehouse.

Community Empowerment approach can be summarized into three life cycle, called "Tridaya" (TKP3 KPK: 2004: 20), namely: 1) Life Cycle of Human Resources Development in the institutional groups of the Poor; 2) Productive Business Development Life Cycle in the institutional group poor people; and 3) Cycle Institutional Group of the poor.

According Rosnita (2012) Human Resources empowerment which is the ability to use their own potential and environment tailored to the social and cultural potential of agriculture. Empowerment of human resources is expected to address the problem of poverty through improving the quality of human resources so that the agricultural community is able to master the technology 
Table 8. Human resource empowerment of farmers

\begin{tabular}{clcc}
\hline No & \multicolumn{1}{c}{ Human Resource } & Score & Category \\
\hline 1 & Increased knowledge of farming & 2,63 & Empowerment Enough \\
2 & A change in the attitude towards the better farming & 2,64 & Empowerment Enough \\
3 & Upgrading skills in farming & 2,14 & Less Empowerment \\
\hline & Average & 2,47 & Less Empowerment \\
\hline
\end{tabular}

in using and managing natural resources capable of sustainable economic empowerment of farmers so that they can create jobs. The level of empowerment of human resources at the plantation farmers self-seen pattern of three indicators, namely: increased knowledge of farming, farming attitude change in a better direction, and improvement of skills in farming.

Table 8 explains that the extension activities carried out FEA is still not able to make a better farmer, which can be seen from the ability of farmers less powerful with a score of 2.47. Although the extension activities already undertaken by educator well, but the extension is only able to change knowledge and attitudes of farmers in farming towards a better place, but have not been able to improve the skills of farmers to better farming. It is seen from the productivity of plantation crops (oil palm and rubber) produced by oil palm growers and farmers' self-help pattern rubber remains below the average productivity of oil palm growers and farmers plasma pattern rubber SRDP.

According Rosnita (2012), the productive economy, namely economic activities of the people who cultivated either individually or in groups, and are capable of processing venture capital to achieve more optimal results. Economic empowerment is expected to create economically productive activities that can increase revenue and create jobs so that capable people's independence. Empowerment of farmers plantations in Riau Province can be seen from the productive economy are presented in Table 9.

Table 9. The economic empowerment of productive farmers

\begin{tabular}{ccrc}
\hline No & Productive Economy & Score & Category \\
\hline 1 & Increased amount of capital & 2,39 & Less Empowerment \\
2 & Increased number of workers & 2,59 & Less Empowerment \\
3 & Increased profit & 2,38 & Less Empowerment \\
\hline & Average & 2,45 & Less Empowerment \\
\hline
\end{tabular}

Table 9 explained that the empowerment of plantation workers in the productive economy is still in the category of " Less Empowerment " is shown with an average score of 2.45. Extension activities undertaken have not been able to increase the amount of venture capital the farmers, which has not seen significant changes to the area of land cultivated, labor usage is dominated by labor in the family and the majority of farmers still are able to hire workers from outside the family with a system of wages, The use of labor from outside the family only do farmers at certain times such as when harvesting the oil palm farmers.

In terms of non-profit farmer planters still less powerful because it has not been able to increase profits plantation business is done optimally. This is because farmers have not been able to increase the area of land managed, business productivity is still low due to limited skills in managing land 
owned so that benefits farmers are still limited and farming is still subsistence income is only able to meet the needs of families and have not been able to invest in order to develop business.

Institutional or "social form". like the organs in the human body. Institutional empowerment will be reflected on the performance achieved by the institutions. Institutional performance (institutional performance), is the ability of an institution to use its resources efficiently and produce output in accordance with its objectives and relefan to user needs. Three things to note are: institutional effectiveness in achieving its objectives, efficient use of resources, and institutional sustainability interact with outside interest groups (Syahyuti, 2003).

Institutional Mardikanto express a form of social relations, which has four components, namely the person component, where people involved in one institution can be identified clearly. Components of interest, where people are definitely being bound by an interest or goal. Components rules, where each institution to develop a set of agreements that are held together, the component structure, where each person has a position and role, which must be executed properly (Mardikanto, 2009). Institutional empowerment of farmers can be seen in Table 10 .

Table 10 shows the extension service and farmers have enough power to develop its institutional showed with a score of 3.35 . Farmers have been very powerful in shaping farmers groups, where the group already has an institutional structure consisting of a chairman, secretary and treasurer. The group has been powerless in determining the group's goals in order for them to obtain information and place of learning in addressing the problem, especially in marketing when the prices of commodities produced are not siding with the farmers. The farmer group has been powerless in achieving the group's goals, objectives formation of farmer groups already be felt by farmers. This can be seen in the district of Mount Toar Farmers have an auction system in the marketing of rubber produced and the prices obtained by farmers is higher than the price offered by the toke. Traders can buy and bring the production of farmers is that offers the highest price of rubber, sometimes winning bidder came from outside Riau such as Jambi, Padang, and southern Sumatra. However, a new farmer group assembles quite helpless in the Definitive Plan Group (DRC) and the Definitive Plan of Group because farmers are assisted by counselors in preparing $\mathrm{RDK}$ and $\mathrm{RDKK}$

Table 10. The Institutional empowerment of farmers

\begin{tabular}{llll}
\hline No & \multicolumn{1}{c}{ Institutional } & Score & \multicolumn{1}{c}{ Category } \\
\hline 1 & Farmer groups have clear objectives & 3,64 & Empowerment \\
2 & Interest farmer groups reached & 3,38 & Empowerment \\
3 & Farmer groups have a clear structure & 4,30 & Very Empowerment \\
4 & Farmer groups preparing RDK & 2,92 & Empow. Enough \\
5 & Farmer groups preparing RDKK & 2,50 & Empow. Enough \\
\hline & Average & 3,35 & Empow. Enough \\
\hline
\end{tabular}

Recapitulation of self-empowerment of farmers plantations in Riau Province patterns described in the variables of empowerment and human resources (HR), productive economic empowerment, and empowerment of institutions can be summarized in Table 11. Table 11 explains that the extension activities undertaken to farmers self plantations in Riau Province is only able to make farmers and farmer groups will be powerful enough indicated by a value of 2.76. Extension Agent 
has been able to increase the empowerment of farmers like motivating farmers to form kelompoktani useful for farmers to exchange information related to farming. Nonetheless extension activities are less able to empower human resources and productive economy of farmers, because the extension activities have not been able to improve farmers' skills in managing farming and farm productivity (rubber and oil palm) that farmers are still under the average productivity of smallholders (palm) and rubber (SRDP).

Table 11. Recapitulation plantation farmer empowerment

\begin{tabular}{cccl}
\hline No & Empowerment & Score & \multicolumn{1}{c}{ Category } \\
\hline 1 & Human Resource & 2,47 & Less Empowerment \\
2 & Productive Economic & 2,45 & Less Empowerment \\
3 & Institutional & 3,35 & Empowerment Enough \\
\hline & Average & 2,76 & Empowerment Enough \\
\hline
\end{tabular}

\subsection{Independence Smallholders Govern- mental Pattern}

Farmer independence became very important in this global era to the opening of outside influences greatly to farm products. In order to improve the competitiveness of the product farming, then the strategy of extension to developing human resources (HR) agriculture upcoming redirected so that they can be more independent in carrying out their farming, which is characterized by its ability to make decisions farming critically, improve the efficiency of utilization of available resources, and increase work productivity.

Farmer independence became very important in this global era to the opening of outside influences greatly to farm products. In order to improve the competitiveness of the product farming, then the strategy of ex- tension to developing human resources (HR) agriculture upcoming redirected so that they can be more independent in carrying out their farming, which is characterized by its ability to make decisions farming critically, improve the efficiency of utilization of available resources, and increase work productivity. (Lestari, 2011).

Farmer independence to take decisions in the selection of commodities namely the ability of farmers to choose the type of commodity sought. More details are presented in Table 12. Table 12 explains that the extension activities undertaken new educator is able to make the farmers self sufficient with a score of 2.77. Quite mandirinya these farmers especially in decision-making in choosing the types of commodities that are cultivated, but still dominant in others involved in selecting the type of commodities are cultivated. It is seen that the influence of the other parties was decisive for farmers in choosing the type of commodity sought.

Table 12. Independence to take decisions in choosing the type of commodity farmers

\begin{tabular}{cccc}
\hline No & \multicolumn{1}{c}{ Commodity } & Score & \multicolumn{1}{c}{ Category } \\
\hline 1 & $\begin{array}{l}\text { Commodities cultivated } \\
\text { types }\end{array}$ & 2,98 & Independece Enough \\
2 & $\begin{array}{l}\text { Considerations in choosing } \\
\text { the type of commodity } \\
\text { Parties involved in the } \\
\text { selection of commodities }\end{array}$ & 2,83 & Independece Enough \\
\hline$\quad$ Average & 2,77 & Independece Enough \\
\hline
\end{tabular}

Independence decision-making in the fulfillment of the means of production, ie the ability of farmers to access agricultural inputs, as seen from the basic consideration in the fulfillment of the means of production and those involved in the process of fulfilling the means of production. For more details can be seen in Table 13 . 
Table 13 reveals that extension activities are only able to make the farmers self sufficient in developing its plantation business. It is especially in the determination of the means of production used. In fulfillment means farmers and kelompoktani still involves a toke in the fulfillment of agricultural inputs are needed, so that the lower level of independence compared with the choice of the means that will be used.

Table 13. Independence to take decisions in the fulfillment of production facilities

\begin{tabular}{cccc}
\hline No & \multicolumn{1}{c}{ Facility } & Score & \multicolumn{1}{c}{ Category } \\
\hline 1 & $\begin{array}{l}\text { Consideration in } \\
\text { determining facilities of } \\
\text { production }\end{array}$ & 2,80 & Independence Enough \\
2 & $\begin{array}{l}\text { Parties involved in the } \\
\text { fulfillment of production } \\
\text { facilities }\end{array}$ & 2,62 & Independence Enough \\
\hline \multicolumn{1}{c}{ Average } & 2,71 & Independence Enough \\
\hline
\end{tabular}

Independence of decision-making in determining the ability of farmers in determining the price of the commodity produced for the market as seen from a consideration in determining the price and the parties involved in the pricing process, which can be seen in Table 14.

Table 14. The independence to make decisions on pricing

\begin{tabular}{cccc}
\hline No & Pricing & Score & Category \\
\hline 1 & $\begin{array}{l}\text { Considerations in } \\
\text { determining the price } \\
2\end{array}$ & 2,15 & Less Independence \\
$\begin{array}{l}\text { Parties involved in } \\
\text { pricing }\end{array}$ & 2,22 & Less Independence \\
\hline \multicolumn{2}{c}{ Average } & 2,19 & Less Independence \\
\hline
\end{tabular}

Table 14 illustrates that extension activities have not been able to make independent farmers in determining the price of the commodity that is marketed. It is shown that the conditions are less mandirinya farmers, especially in the pricing process. This caused that the dependence of most farmers to toke in the commodity market, because of the dependence of farmers to toke in the fulfillment of their production facilities so that farmers have no other alternative to marketing, in addition to toke. Besides, farmers can not be separated from toke in pricing because it was the establishment of patron-client system (foster parents) in developing its plantation business.

The independence to make decisions in marketing,in the ability of farmers to develop their farming produce market, which is described by the marketing of farming, the benefits and savings from the farm. For more details can be seen in Table 15 .

Table 15. The independence to make decisions in marketing

\begin{tabular}{cccc}
\hline No & Marketing & Score & Category \\
\hline 1 & Marketing of farming & 2,95 & Independence Enough \\
2 & Profits earned & 2,22 & Less Independence \\
3 & Deposits from the farm & 2,17 & Less Independence \\
\hline & Average & 2,44 & Less Independence \\
\hline
\end{tabular}

Table 15 illustrates that the extension efforts have not been able to make independent farmers in marketing. Farmers have been quite independent in the marketing of farming which in usahtani rubber kelompoktani in the District of Mount Toar has been able to market the auction system so that they are not tied to toke and able to get a higher price than the price at the toke, but the benefits of farmers is still very limited so that farmers are not able to save money in a relatively large amount for a new earned income sufficient to meet the needs of families.

Independence recapitulation pattern plantation farmer self-help in Riau province on the ability to make decisions in the selection of commodities, the fulfillment of the 
means of production, in pricing and marketing are presented in Table 16.

Table 16. Recapitulation Independence Farmers

\begin{tabular}{clcc}
\hline No & \multicolumn{1}{c}{ Independence } & Score & \multicolumn{1}{c}{ Category } \\
\hline 1 & $\begin{array}{l}\text { In the selection of } \\
\text { commodity type }\end{array}$ & 2,77 & Independence Enough \\
2 & $\begin{array}{l}\text { In fulfillment of the } \\
\text { means of production }\end{array}$ & 2,71 & Independence Enough \\
3 & $\begin{array}{l}\text { In price decision } \\
4\end{array}$ & 2,19 & Less Independence \\
& $\begin{array}{l}\text { In the marketing of } \\
\text { farm }\end{array}$ & 2,44 & Less Independence \\
\hline \multicolumn{1}{c}{ Average } & 2,53 & Less Independence \\
\hline
\end{tabular}

Table 16 illustrates that the educator extension activities that do still make farmers unable to act independently on farming activities of oil palm and rubber plantations cultivated. This is mainly due to the dependence of farmers is very high in the fulfillment of production facilities that make farmers dependent. These conditions resulted in most farmers do not have the power to set prices and have no other alternative but to sell their oil palm and rubber marketed to own market.

Various aid have also been carried out starting from subsidies with production facilities, direct capital assistance, farm loans, and so forth that number is very diverse. But there are still some farmers are still low income, they depend on a variety of assistance, and they are always thinking has not been able to move on their own in carrying out their farming. This is in accordance with the opinion of Lestari (2011) that the programs of agricultural extension has been running, has not been able to optimally help the farmers to improve their living standards, and to encourage farmers to find a solution to their own problems in carrying out their farming.

\section{Conclusions}

The performance of educator in conducting outreach to non-plantation workers have good pattern with a score of 3.41. Extension Agent has been doing preparatory extension very well with a score of 4.58 , but the performance educator to the implementation of the extension is still at a low level compared to the preparation and evaluation of performance reporting.

Extension activities on the plantation farmers who do make the educator educator quite helpless with a score of 2.76. Quite helpless farmers especially at the institutional farmers, but the human resources and productive economy is still less powerful farmers. This is because the extension has not been able to improve their skills, so that productivity and farmers' income remains below the average farmers.

The performance of educator who has been excellent in conducting outreach to non-plantation workers still make farmers unable to act independently with a score of 2.53. Mandirian lack of farmers, especially in pricing and marketing. Most farmers are still dependent on toke make make farmers have no bargaining power in price and still do a marketing system with the model of patron-client (foster father).

\section{References}

Adefila JO. (2012). Spatial Impact of Extension Workers' Performance on Sustainable Agricultural Develompment in Kaduna State of Nigeria. Journal of Sustainable Development Volume 5 No 4, April 2012, pp 141-148. 
Agency for Agricultural Education and $\mathrm{Hu}-$ man Resources Development, (2011). Supervising Technical Guidelines Monitoring, Evaluation and Reporting in 2011. Jakarta.

Bahua Muhammad Ikbal, Arsyad Muhammad, Jamil Muh Hatta. (2016). Farmers Community Empowerment through Institusonal Strengthening of Rural Food Barn. International Journal of Agriculture System (IJAS), 4(2):161167.

Central Bureau of Statistics (BPS) Riau Province. (2014). Rokan Hilir. Rokan hilir in number 2014. Riau. Pekanbaru.

David, Magoro M, Samuel, Hlungwani S. (2014). The Role of Agriculture Extension in the 21 Century Reflections From Africa. International Journal of Agricultural Extension. Volume 02 (01), pp 89-93.

Dinas Perkebunan of Rokan Hilir. (2013). Statistics Plantation Rokan Hilir. 2012. Rokan Hilir.

Dirjen Perkebunan, (2014). The land area and production plantationspalm oil every province in Indonesia. Plantation Office of Riau Province. Pekanbaru.

Khalil, O., Hassan, A., Ismail, M., Suandi, T. and Silong, A.D., (2008). Extension Worker As A Leader to Farmers: Influence of Extension Leadership Competencies And Organisational Commitment On Extension Workers'performance In Yemen. Journal of International Social Research, 1(4).

Lestari, M. (2011). Group Dynamics and Self-Reliance Members Farmers farm- ing In District Poncowarno In Kebumen, Central Java Province. Thesis Graduate Program of Sebelas Maret University, Surakarta

Mardikanto, (2009). Extension Agricultural Development. Sebelas Maret University Press. Surakarta

Regulation of the Ministry of Agriculture No. $\quad$ 91/Permentan/OT.140/9/2013. Performance Evaluation of Agricultural Extension.

Rehman F, Muhammad S, Ashraf I, Mahmood Ch K, Ruby T and Bibi I. (2013). Effect of Farmer's Socioeconomic Characteristics on Access to Agricultural Information:Emperical Evidence From Pakistan. The Journal of Animal \& Plant Sciences, 23 (1), pp 324-329. Rosnita, (2012). The level of empowerment Microfinance Institutions in Increasing Production of Palm Oil in Riau Province. Proceedings of the National Seminar and Annual Meeting of the Division of Agricultural Sciences BKSPTN Western Conference in 2012, 3 - 5 April 2012. Agriculture Faculty of Sumatera Utara University.

Rosnita, Yulida Roza, Dewi Novia, Arifudin, Andriani Yulia. (2016). Impact Extension Independence Empowerment Against Palm Oil Growers Governmental pattern in Riau Province in the Proceedings of the Workshop and Seminar "Looking for Empowerment and Revitalization Plantation Model for Indonesia Sustainable Palm Oil, pp: 94-105

Sapar, (2011). Factors That Influence On Agricultural Extension Performance 
Competence and its Impact on Regional Cocoa Farmers In Four South Sulawesi. Undergraduate Forum Vol. 34 No. 4: 297-305

Sugiyono, (2011). Educational Research Methods. Alfabeta.Bandung

Syahyuti. (2003). Surgical Concepts Institutional: Development Strategy and Its Application in Agricultural Research. IAARD. Bogor.
TKP3 KPK. (2004). General Guidelines for Village Empowerment (PPD). Community Empowerment and Protection Agency. Goverment of Riau Province Law No 16 of 2006. Extension System of Agriculture, Fisheries and Forestry. (online serial) 10 November 2012. http://www.deptan.go.id/feati/dokumen/uu_sp3k.pdf. Accessed February 27, 2015. 